\title{
Study on Market and Income Profiles of Traditional Bandha Weavers for Livelihood Generation in Cuttack District of Odisha, India
}

\author{
Shubhasri Sahoo ${ }^{1}$, Pranati Das ${ }^{1}$ and Bibhuti Prasad Mohapatra ${ }^{2}$ \\ ${ }^{1}$ Department of Textile and Apparel Designing, College of Community Science, \\ OUAT, Bhubaneswar-751003, Odisha, India \\ ${ }^{2}$ Department of Agricultural Extension, College of Agriculture, OUAT, \\ Bhubaneswar-751003, Odisha, India \\ *Corresponding author
}

\section{Keywords}

Handloom, Bandha, Bandha weavers, Marketing, Income Indebtedness

Article Info

Accepted:

18 May 2020

10 June 2020 profile,

Available Online:

\section{A B S T R A C T}

Handloom has long association with tradition and culture of India. The unique Bandha design and Bandha weaving were the traditional and principal occupation of Bandha weavers of Odisha for their livelihood.Keeping in view the above facts, present study was carried out in Cuttack district of Odisha to assess the economic conditions of Bandha weavers. A total of 153 respondents were interviewed from three villages for data collection by using purposive and simple random sampling techniques. It was observed that $21.57 \%$ of weavers sell their terminal products directly, $16.34 \%$ through master weavers and $8.5 \%$ through weavers co-operative society mainly. They were facing constraints in marketing. Majority $(50.33 \%)$ of weavers had monthly income within Rs.5000/ and 39.22\% had Rs.5001/ to Rs.10000/.Majority(59.48\%) of weavers had availed credit from various credit sources.54.95\% had availed credit up to Rs.40000/- only and 34.07\% had Rs.40001/-Rs.80000/.It indicated that they need adequate financial support for weaving to improve their livelihood system. Some recommendations were forwarded to Govt. for sustainability of indigenous Bandha design and Bandha weaving as well as improvement in livelihood system of Bandha weavers in the costal part of Odisha.

\section{Introduction}

Indian handloom industry occupies an eminent place in preserving country's heritage and culture. It plays a vital role in the economy of the country as well as occupied second place only to agriculture in terms of employment (Raju and Rao, 2014). It contributes to $7 \%$ of industry output in value terms, $2 \%$ of India's GDP and to $15 \%$ of the country's export earnings. It employed over 45 million people directly in the country and is an integral part of the rural and semi-rural livelihood (Annual report, Govt. of India, 2018).

Odisha has one of the richest traditions of handlooms in the country. Its Ikat textiles influenced the handloom industries of the state. 
It has an advantage of being less capital intensive, minimal use of power, eco-friendly, flexibility of small production, openness to innovations and adaptability to market requirements. It is one of the natural productive asset and tradition at cottage level which sustained and grown by transfer of skill from generations to generations. The weavers of this industry have kept alive the traditional craft of handloom which has been appreciated throughout the country and in abroad because of its exquisite designs, natural motifs and superb colour combination. The level of artistry and intricacy achieved in the handloom fabrics is unparalled and are still beyond the scope of the modern machines (Mishra, 2018). Odisha holds $4^{\text {th }}$ position in India in registered GIs (14). Out of 14 goods, 9 textile items are registered by the Department of Textiles, Government of Odisha and Ikat fabrics are come under such registered goods (Raju and Chaudhary, 2013).

Odisha Ikat locally called Bandha which is internationally termed as Ikat and nationally termed as tie and dye means to bind, knot or wind around. It is a resist dyeing process in which tying and dyeing of yarn is done by hand before weaving (Mohanty and Krishna, 1974). In Odisha, it is in existence from 12th Century AD at Nuapatna, Cuttack as per Madala Panji of Jagannath Temple (Behera, Khandual and Luximon, 2019).The Bandha technique of weaving is much more intricate than simple handloom weaving.

From ancient times, highly skilled Bandha weavers are Bhulia and Kostha weavers of western districts and Gaudia, Asani pataras and Sarakas (Buddhists) of coastal districts of Odisha (Das et al., 1994).Nuapatna village of Tigiria block in Athagarh sub division of Cuttack district of Odisha occupies a distinct place in the handloom map of the state having 5000 registered weavers (Panda and Parida, 2019).
But now weavers are facing several constraints like poverty, Exploitation, Unemployment, indebtedness, lack of marketing, lack of information, problems of finance, problem of middlemen etc. The civilized traders, middlemen and religious missionaries economically exploited the rural people (Mishra, 2018).

Weavers are migrating to another profession due to many reasons such as meagre remuneration, generation of low income, insufficient working capital, insufficient marketing facilities, lack of technological upgradation, inadequate credit availability, lack of contemporary designs and younger generations are not interested in taking handloom as a profession (Amaravathi and Bhavana Raj, 2019).

In the above context, the present research work is carried out at Department of Textile and Apparel Designing, College of Community Science under Orissa University of Agriculture and Technology, Bhubaneswar, Odisha with the following objectives include to study about market profiles of Bandha weavers. To study about income profiles and indebtedness of Bandha weavers. Also to study about the effect of social variables on marketing.

\section{Materials and Methods}

\section{Location of survey area}

The present study was undertaken in three Bandha producing villages namely Nuapatana, Maniabandha, Ragadipatana of gram-panchayat Nuapatana, Maniabandha, Ragadi of blocks Tigiria(Athagarh subdivision), Baramba and Banki-II/Banki damapara ( Banki sub-division)respectively of Cuttack district, coming under east coastal plain zone of Odisha. 


\section{Experimental design}

Ex-Post facto Survey research design was considered to gather data. The district, subdivisions, blocks, gram panchayats were selected purposively. Simple random sampling techniques were followed to select villages and respondents making the total sample size of 153 .

\section{Techniques employed}

A total of 153 respondents were interviewed for data collection by close ended questions. The data collected were tabulated and statistically analysed with the help of frequency, percentage, Pearson's correlation co-efficient and multiple regression.

\section{Results and Discussion}

\section{Market profile}

Easy disposal of the produce with remunerative price very often motivate the weavers for preparing more products. So in the study areathe data collected on market profile of weavers were analysed and was enlisted in table 1.

From the table it is revealed that mixed responses were obtained from the respondents about marketing of the produce. No single respondents sell their products through SHG, NGO, Boyanika (the apex society) and emarketing. Negligible percentage $(1.31 \%)$ of the respondents had stated for marketing through traders, through traders and master weavers, direct selling and through trades, direct selling and through weaver cooperative society and traders.

Marketing through weaver cooperative society along with master weavers, traders and through exhibitions were not encouraging and only $2.61 \%$. Similarly, marketing through direct selling and weaver cooperative society as well as direct selling, weavers cooperative society and master weavers were only $11.11 \%$. At the same time marketing through direct selling and master weavers was only $9.15 \%$ and through weavers co-operative society and master weavers by $18.76 \%$ of the respondents.

Comparatively more marketing were observed through direct selling $(21.57 \%)$ and through master weavers (16.34\%).selling through weaver cooperative society was only $8.50 \%$. The findings showed that the weaver depends on number of sources to sell their products. They were facing constraints in marketing of the product and might have not got remunerative price.

\section{Income generation}

Financial soundness is the indicator of empowerment and adoption of improved technologies. So the data collected on approximate income generated by the weavers per month on handloom products have been analysed and was enlisted in table 2 .

From the table it is revealed that Monthly income of the respondents through weaving was not encouraging. Majority (50.33\%) of the respondents were generating meagre income of within Rs.5000/- per month followed by $39.22 \%$ for generating monthly income of Rs.5001/ to Rs.10000/. Very few respondents were generating monthly income of Rs.10001/ to Rs.15000/ (6.53\%), Rs.15001/ to Rs.20000/ (2.61\%) and above Rs.20001/ (1.31\%).

The findings showed that the respondents were facing problems in good infrastructural facilities, insufficient or lack of tools and equipments, getting quality raw materials as well as marketing of the products resulting low income. Also the respondents were 
relatively resource poor and might have opting for their traditional occupation of weaving on compulsion. Further attempt have been made to analyse the income generated from other sources by the family members of the respondents. The data collected from respondents were analysed and enlisted in the table3.

From the table it is revealed that $82.35 \%$ of family members of the respondents had no income. They fully dependent on the respondents and assisting them in his Bandha work. Out of the rest $9.15 \%$ of family members of the respondents had subsidiary income of within Rs.5000/month and rest $8.50 \%$ had additional income per month ranging from Rs.5001/ to above Rs.20001/ per month and the sources were business and service in both private as well as Government Sector.

The findings showed that the respondents were very poor and majority of family members of the respondents had monthly income within Rs.5000/ which definitely a burden to the respondents to maintain their family.

\section{Indebtedness}

Credit and finance are the essential key factors for successful management of any activities. Since, the Bandha weavers are relatively resource poor, they essentially need adequate financial support. So data collected on indebtedness of the respondents have been analysed and enlisted in the table4. From the table it is revealed that majority $(59.48 \%)$ of respondents had availed credit from various credit sources such as nationalised and rural as well as cooperative banks, master weavers, SHG, private money lender, friends \& relatives with some interest. Rest $40.52 \%$ of the respondents not availing credit may be defaulters or having lack of repayment capability. The findings showed that the respondents essentially need financial support for weaving. So, further attempt have been made to assess the amount of credit availed by the respondents. The data collected have been analysed and enlisted in table 5 .

From the table it is revealed that majority $(54.95 \%)$ of respondents had availed loan up to Rs.40000/- only. Only $34.07 \%$ have taken Rs.40001/-80000/, 5.49\% within Rs.80001/1.0 lakh (L), 3.30\% within Rs.1.0 lakh-2.0(L) and rest $2.19 \%$ availed above 2.0(L). Availing loan within Rs.40000/ is not an adequate amount for undertaking weaving for getting substantial income. The findings showed that adequate financial support is required to the weavers to improve their vocation and livelihood system and subsidy in loan should be provided to the weavers for their betterment.

\section{Effect of social variables on marketing}

Further attempt have been made to assess the influence of socio-economic variables on marketing. Pearson's correlation co-efficient analysis was therefore made and the results have been enlisted in table 6 .

Correlation co-efficient analysis revealed that gender, family type, education, caste and card holder attributes of the respondents have no influence on input use and producing terminal products. In other words, age, occupation, work experience, sources of learning, working hours per day, accommodation facility, possession of tools and techniques, work category and membership status of the respondents had positively and significantly influence towards marketing. Further attempt have been made for the multiple regression analysis of the socio-economic variables to locate the causal impact on the consequent factors towards accelerating marketing of the products. 
Table.1 Marketing facilities available to the respondents $(\mathrm{n}=153)$

\begin{tabular}{|c|c|c|c|}
\hline Sl.no. & Types of marketing & Frequency & Percentage \\
\hline $\mathbf{1}$ & DS & 33 & 21.57 \\
\hline $\mathbf{2}$ & Through WCS & 13 & 8.50 \\
\hline $\mathbf{3}$ & Through MW & 25 & 16.34 \\
\hline $\mathbf{4}$ & Through Traders & 2 & 1.31 \\
\hline $\mathbf{5}$ & Through WCS \& MW & 18 & 11.76 \\
\hline $\mathbf{6}$ & Through MW \&Traders & 2 & 1.31 \\
\hline $\mathbf{7}$ & DS\& through WCS & 17 & 11.11 \\
\hline $\mathbf{8}$ & DS \& through MW & 14 & 9.15 \\
\hline $\mathbf{9}$ & DS \& through WCS \&MW & 17 & 11.11 \\
\hline $\mathbf{1 0}$ & DS \& through Traders & 2 & 1.31 \\
\hline $\mathbf{1 1}$ & DS\& through WCS \& Traders & 2 & 1.31 \\
\hline $\mathbf{1 2}$ & Through WCS \& MW \&Traders & 4 & 2.61 \\
\hline $\mathbf{1 3}$ & Through Exhibition & 4 & 2.61 \\
\hline
\end{tabular}

Note: DS-Direct Selling, WCS: Weavers Co-operative society, MW-Master Weaver

Table.2 Income generated on handloom products per month by the respondents $(n=153)$

\begin{tabular}{|c|c|c|c|}
\hline Sl.no & Income/month & frequency & Percentage \\
\hline $\mathbf{1}$ & Up to 5000/ & 77 & 50.33 \\
\hline $\mathbf{2}$ & $5001 /-10000 /$ & 60 & 39.22 \\
\hline $\mathbf{3}$ & $10001 /-15000 /$ & 10 & 6.53 \\
\hline $\mathbf{4}$ & $15001 /-20000 /$ & 4 & 2.61 \\
\hline $\mathbf{5}$ & Above $20001 /$ & 2 & 1.31 \\
\hline
\end{tabular}

Table.3 Income generated by the family members of the respondents per month from other activities $(n=153)$

\begin{tabular}{|c|c|c|c|}
\hline Sl.no & $\begin{array}{c}\text { Family income of weaving households per } \\
\text { month from other activities }\end{array}$ & frequency & Percentage \\
\hline $\mathbf{1}$ & Dependent(No income) & 126 & 82.35 \\
\hline $\mathbf{2}$ & Up to 5000/ & 14 & 9.15 \\
\hline $\mathbf{3}$ & $5001 /-10000 /$ & 3 & 1.96 \\
\hline $\mathbf{4}$ & $10001 /-15000 /$ & 3 & 1.96 \\
\hline $\mathbf{5}$ & $15001 /-20000 /$ & 4 & 2.61 \\
\hline $\mathbf{6}$ & Above 20001/ & 3 & 1.96 \\
\hline
\end{tabular}

Table.4 Extent of indebtedness of the respondents $(n=153)$

\begin{tabular}{|c|c|c|c|}
\hline Sl.no & Indebtedness availed & Frequency & Percentage \\
\hline $\mathbf{1}$ & Availed & 91 & 59.48 \\
\hline $\mathbf{2}$ & Not availed & 62 & 40.52 \\
\hline
\end{tabular}


Table.5 Extent of debt availed by the respondents $(\mathrm{n}=91)$

\begin{tabular}{|c|c|c|c|}
\hline Sl.no & Amount of debt & Frequency & Percentage \\
\hline $\mathbf{1}$ & Up to 40000/ & 50 & 54.95 \\
\hline $\mathbf{2}$ & $40001 /-80000 /$ & 31 & 34.07 \\
\hline $\mathbf{3}$ & $80001 /-1 \mathrm{Lakh}$ & 5 & 5.49 \\
\hline $\mathbf{4}$ & 1Lakh-2 Lakh & 3 & 3.30 \\
\hline $\mathbf{5}$ & Above 2Lakh & 2 & 2.19 \\
\hline
\end{tabular}

Table.6 Influence of socio-economic variables on marketing

\begin{tabular}{|c|c|c|}
\hline Sl.no & Variables & Correlation ('r') value \\
\hline $\mathbf{X}_{\mathbf{1}}$ & Age & $0.246^{* *}$ \\
\hline $\mathbf{X}_{\mathbf{2}}$ & Gender & 0.028 \\
\hline $\mathbf{X}_{\mathbf{3}}$ & Family type & 0.154 \\
\hline $\mathbf{X}_{\mathbf{4}}$ & Education & 0.146 \\
\hline $\mathbf{X}_{\mathbf{5}}$ & Caste & 0.106 \\
\hline $\mathbf{X}_{\mathbf{6}}$ & Card holder & 0.051 \\
\hline $\mathbf{X}_{\mathbf{7}}$ & Occupation & $0.490^{* *}$ \\
\hline $\mathbf{X}_{\mathbf{8}}$ & Work experience & $0.567^{* *}$ \\
\hline $\mathbf{X}_{\mathbf{9}}$ & Sources of learning & $0.548^{* *}$ \\
\hline $\mathbf{X}_{\mathbf{1 0}}$ & Working hours per day & $0.271^{* *}$ \\
\hline $\mathbf{X}_{\mathbf{1 1}}$ & Accommodation facility & $0.517^{* *}$ \\
\hline $\mathbf{X}_{\mathbf{1 2}}$ & Possession of tools and techniques & $0.324^{* *}$ \\
\hline $\mathbf{X}_{\mathbf{1 3}}$ & Work category & $0.548^{* *}$ \\
\hline $\mathbf{X}_{\mathbf{1 4}}$ & Membership status & $0.708^{* *}$ \\
\hline
\end{tabular}

** Significant at 0.01 level * Significant at 0.05 level

Table.7 Multiple regression of socio-economic variables influencing marketing $(\mathrm{n}=153)$

\begin{tabular}{|c|c|c|c|c|c|c|c|}
\hline $\begin{array}{c}\text { Sl. } \\
\text { No. }\end{array}$ & Variable & \multicolumn{2}{|c|}{$\begin{array}{c}\text { Unstandardized } \\
\text { Coefficient }\end{array}$} & \multicolumn{2}{|c|}{ Standardized Coefficient } & 't' value & Probability \\
\cline { 1 - 7 } & & Beta & Std. Error & Beta & Std. Error & & \\
\hline $\mathbf{X}_{\mathbf{1}}$ & Age & -1.465 & 0.530 & -0.262 & 0.109 & $-2.764^{* *}$ & 0.006 \\
\hline $\mathbf{X}_{\mathbf{2}}$ & Gender & -1.427 & 1.559 & -0.040 & 0.305 & -0.915 & 0.362 \\
\hline $\mathbf{X}_{\mathbf{3}}$ & Family type & -1.392 & 0.716 & -0.128 & -0.034 & -1.945 & 0.054 \\
\hline $\mathbf{X}_{\mathbf{4}}$ & Education & -0.833 & 0.330 & -0.244 & 0.129 & $-2.528^{* *}$ & 0.013 \\
\hline $\mathbf{X}_{\mathbf{5}}$ & Caste & -0.449 & 0.641 & -0.067 & -0.160 & -0.700 & 0.485 \\
\hline $\mathbf{X}_{\mathbf{6}}$ & Card holder & -0.617 & 0.360 & -0.109 & 0.551 & -1.714 & 0.089 \\
\hline $\mathbf{X}_{\mathbf{7}}$ & Occupation & 0.740 & 0.322 & 0.256 & 0.018 & $2.298^{*}$ & 0.023 \\
\hline $\mathbf{X}_{\mathbf{8}}$ & Work experience & 2.175 & 0.587 & 0.256 & -0.139 & $3.703^{* *}$ & 0.000 \\
\hline $\mathbf{X}_{\mathbf{9}}$ & Sources of learning & -0.068 & 0.470 & -0.018 & 0.250 & -0.144 & 0.886 \\
\hline $\mathbf{X}_{\mathbf{1 0}}$ & Working hours per day & -1.871 & 0.509 & -0.387 & -0.083 & $-3.673^{* *}$ & 0.000 \\
\hline $\mathbf{X}_{\mathbf{1 1}}$ & Accommodation facility & 0.418 & 0.640 & 0.044 & 0.109 & 0.652 & 0.515 \\
\hline $\mathbf{X}_{\mathbf{1 2}}$ & Possession of tools and & 0.853 & 0.647 & 0.081 & 0.034 & 1.319 & 0.189 \\
\hline & techniques & & & & & & \\
\hline $\mathbf{X}_{\mathbf{1 3}}$ & Work category & 1.219 & 0.231 & 0.790 & 0.142 & $5.287^{* *}$ & 0.000 \\
\hline $\mathbf{X}_{\mathbf{1 4}}$ & Membership status & 1.178 & 0.325 & 0.347 & 0.331 & $3.622^{* *}$ & 0.000 \\
\hline
\end{tabular}

$\mathrm{R}^{2}-0.751$ Adj $\mathrm{R}^{2}-0.725$ S.E. -2.140 
The results have been enlisted in table 7 . From the table it is revealed that the best fitted regression equation could explain $75.10 \%$ of the total variance in marketing. Among the fourteen variables covered under the study, membership status, work category, working hours per day, work experience, age, education, occupation and family type could exhibit significant influence on marketing of the produce with remunerative price. It is therefore suggested that the organisations associated with promotion of weaving and development of the weavers have to strengthen all these variables ensuring better marketing of the terminal products with remunerative price by the respondents.

The weavers in the study area have the traditional occupation of weaving. They are usually resource poor and fully depend on weaving for their livelihood. They have the constraints of marketing and mostly disposed their terminal products through direct selling, master weavers and weaver's co-operative society. Income generated by the respondents was not encouraging. Majority $(50.33 \%)$ of weaver households had monthly income within Rs.5000/- having no other family income which definitely a burden to the weavers to maintain their family. Similar finding was reported by Govt. of India, Ministry of Textiles, office of the Development Commissioner for Handlooms (2019-20) who stated that majority $(66.3 \%)$ of the weaver households earn less than Rs.5, 000 /- per month. Though around fifty percentage of the respondents were availing credit, but the loan amount was insufficient which is only within Rs.40000/. Therefore, they need adequate financial support for improvement in their livelihood.

\section{Suggestions}

Conversion charge (wages) should be increased, since it is laborious and a traditional art of Odisha.

Skill competency on improved dying and designing.

Good infrastructural facilities with sufficient weaving equipments and tools.

Creating marketing avenues and regular participation in exhibitions and fairs for all weavers.

Introduction of handloom dress code and furnishings in all schools, colleges and Govt.offices for comfort and hygienic in all season and its uniqueness. So that the weavers will get more works and earn more money.

Adequate credit support with subsidized interest.

Introduction of special scheme for Bandha weavers.

Introduction of handloom course compulsory in all institutions.

Strategies for ensuring confidence in youth for taking handloom as a profession.

The state Government developmental department as well as district administration have to analyse all these suggestive measures and extend all feasible supports for more income of the Bandha weavers of Cuttack district of Odisha for their livelihood and sustainability of the said Bandha products.

\section{References}

Amaravathi, G., and Bhavana Raj, K.2019.Indian Handloom Sector - A Glimpse, International Journal of Innovative Technology and Exploring Engineering, 8(6S4): 645-654.

Annual report. 2018. Government of India, Ministry of Textiles, New Delhi.

Behera, S., Khandual, A., and Luximon, Y.2019. An Insight In To the Ikat Technology in India: Ancient To Modern Era, IOSR Journal of Polymer and Textile Engineering (IOSR-JPTE), 6 (1): 28-51. 
Das, P., Behura, N. K., and Mohanty, B. C.1994. Bandha fabrics of Orissa: an aesthetic textile tradition selected case studies, Orissa, India. PhD thesis, Utkal University, Vanivihar, Bhubaneswar, India.

Fourth All India Handloom Census. 2019. Office of the Development Commissioner for Handlooms, Govt. of India, Ministry of Textiles, New Delhi.

Mishra, K. 2018. Socio Economic Growth of Handloom: An Empirical Study, IOSR Journal of Business and Management, 20 (3): 21-34.

Mohanty, B. C., and Krishna, K.1974.Ikat Fabrics of Orissa and Andhra Pradesh,
Calico Museum of Textiles, Ahmedabad, India, Vol. 1.

Panda, S., and Parida, C.2019. A Case for Conservation of the Sustainable Vernacular Weavers' Settlement at Nuapatna, Odisha, International Journal of Applied Engineering Research, 14(6):1420-1425.

Raju, K.D., and Chaudhary, S. 2013. Geographical Indications in Odisha: A Leading Destination of Traditional Handlooms, Odisha Review, 38-44.

Raju, G.N., and Rao, K.V. 2014. A Study on the Socio-economic conditions of Handloom weavers, Journal of Rural Development, 33 (3): 309-328.

\section{How to cite this article:}

Shubhasri Sahoo, Pranati Das and Bibhuti Prasad Mohapatra. 2020. Study on Market and Income Profiles of Traditional Bandha Weavers for Livelihood Generation in Cuttack District of Odisha, India. Int.J.Curr.Microbiol.App.Sci. 9(06): 1175-1182.

doi: https://doi.org/10.20546/ijcmas.2020.906.146 